Vol. 21, n 1 | 2017

Varia

\title{
An Awful and Impressive Spectacle : Crime Scene Executions in Scotland, 1801-1841
}

Rachel Bennett

\section{(2) OpenEdition \\ 12 Journals}

Electronic version

URL: https://journals.openedition.org/chs/1720

DOI: 10.4000/chs. 1720

ISSN: 1663-4837

Publisher

Librairie Droz

Printed version

Date of publication: 1 January 2017

ISSN: 1422-0857

\section{Electronic reference}

Rachel Bennett, "An Awful and Impressive Spectacle : Crime Scene Executions in Scotland,

1801-1841", Crime, Histoire \& Sociétés / Crime, History \& Societies [Online], Vol. 21, n | 2017, Online since 01 January 2019, connection on 21 September 2021. URL: http://journals.openedition.org/chs/ 1720 ; DOI: https://doi.org/10.4000/chs.1720

This text was automatically generated on 21 September 2021.

(c) Droz 


\title{
An Awful and Impressive Spectacle : Crime Scene Executions in Scotland, 1801-1841
}

\author{
Rachel Bennett
}

\section{Introduction}

1 When John Watt was convicted before the Perth Circuit Court for housebreaking and theft in 1801, the judges ordered that his execution would take place at the scene of his crime in Dundee. The Caledonian Mercury stated that "a scene like this, at all times and all places awful and impressive, must be particularly so in Dundee which has not witnessed anything of a similar nature for perhaps a century". The article continued "we understand it is the determination of the Lords of Justiciary that all criminals who are sentenced to die shall be executed in the places where they committed the crimes for which their life is forfeited. This is certainly a wise and salutary measure and we have no doubt will be followed by the most beneficial consequences". ${ }^{1}$ Despite this slight editorial exaggeration, there were thirty-seven offenders sentenced to be executed at, or very near, the scene of their crime between 1801 and 1841, presenting the highest use of this punishment since the mid-eighteenth century. This study will examine the motivations of the Scottish courts in utilising this penal option and explore the multifaceted responses it provoked.

2 Within the rich historiography dedicated to the study of capital punishment in the nineteenth century, studies of the Scottish experience have remained limited. There have been quantitative surveys of Scottish crime using the parliamentary returns, which are more regularly available for the period after 1836, that have highlighted an increase in recorded and prosecuted crime. ${ }^{2}$ In addition, a more recent study provided the first extensive analysis of capital punishment in Scotland across the period between the mideighteenth and early nineteenth centuries. ${ }^{3}$ In furthering this body of work, this article will demonstrate that Scotland was distinct in its use of crime scene executions, 
especially when compared to England. There was no single reason for this difference and instead there were multiple explanations. It is important to note that, in the wake of the 1707 Act of Union (6 Ann c.11), Scotland and England each maintained their own distinct legal systems. There were also marked differences in their use of capital punishment, including crime scene executions. Poole has shown that there were at least 211 people hanged at the scene of their crimes between 1720 and 1830 in England. When breaking down the chronology, he demonstrated that there was a decline in their use after 1790, but sporadic cases persisted into the first third of the nineteenth century. ${ }^{4}$ Comparatively, despite being a penal option in Scotland, these executions were exercised infrequently in the eighteenth century and there were only twenty-one offenders hanged at the scene of their crimes between 1740 and 1799. Twelve of the cases were concentrated between 1746 and 1755 and correlated with a peak in execution levels in the wake of the 1745 Jacobite Rebellion, particularly in northern Scotland. This pattern suggests that they were predominantly used at times of an increase in the sheer number of executions, but crucially also at times when there were evident concerns over the believed prevalence of serious crime as was the case in the early nineteenth century.

This study will argue that the use of crime scene executions in early nineteenth-century Scotland was explicitly linked to trends in capital punishment more widely and the debates over the merits of public punishment. In short, they were a distinct Scottish response to a very British problem. In the eighteenth century, Scotland sent far fewer offenders to the gallows than their southern neighbours and, apart from the mideighteenth-century peak in executions, the Scottish newspapers had not dedicated the same extensive space to crime reporting. However, by the second and third decades of the nineteenth century, the proportion of capitally convicted offenders who were executed fell in England but remained relatively consistent in Scotland. Although the sheer number of executions remained lower, this proportional difference resulted in unprecedented numbers of offenders being sent to the scaffold. ${ }^{5}$ This fact was noted, and lamented, by contemporaries. Therefore, this study will provide some reinforcement to the argument briefly made by Crowther, namely that in Scotland, rather than keeping the number of executions to a socially acceptable level, as appeared to be the case in England, unprecedented numbers of capital convictions led to a belief that it was necessary to maintain, or in the case of crime scene executions increase, levels of exemplary punishment. ${ }^{6}$

4 The article will be structured into four key sections. The first will examine the drivers behind the courts' sentencing of crime scene executions. It will question if the age of offenders, the crimes they had committed and the locations at which they were judicially tried impacted upon the decisions. It will explore the role of public discourse and the judges in justifying these spectacles. It is important to note that it is not the intention to question if crime scene hangings, or indeed any executions, were a successful deterrent from crime. The fact that the public execution spectacle had been a long standing focal part of the British criminal justice system demonstrates that they were not. Instead, this study explores the importance of the motivations of deterrence and the infliction of some harsher form of punishment to the death sentence in the minds of the contemporary legal authorities when justifying the use of crime scene executions.

5 The methodology adopted to construct this analysis involved an extensive exploration of the minute books of the High Court in Edinburgh and those of the three circuit courts to catalogue the details of every offender sentenced to death between 1800 and 1841 . This 
analysis was then bolstered by sources rich in qualitative detail, including the previously neglected Home Office papers related to Scottish crime that offer invaluable information about the motivations of the authorities in sentencing offenders to be executed at the scene of their crime. Prior to the late eighteenth century, Scottish crime reporting was minimal and offered limited journalistic opinion. ${ }^{7}$ However, by the early nineteenth century crime reporting occupied an increased space and cases of a capital nature warranted more in-depth discussion as they were believed to be reaching unprecedented levels. Kilday argues that this alarming representation of the frequency of crime played a key part in the "burgeoning misconception surrounding Scottish crime" as criminal indictments remained lower than in other countries. ${ }^{8}$ However, what is clear is that the sheer number of offenders suffering the death sentence had reached new heights by the second decade of the nineteenth century and, for the purposes of this article, a reading of the "panic" over crime in the newspapers offers the potential to understand why the authorities turned to crime scene executions which, prior to this period, had been used on an infrequent basis.

6 The second section of this study will investigate how the executions were shaped in practice. It will include a discussion of key elements of the scaffold ritual such as the need for lengthy processions from the places of confinement that were contrary to modern execution practices but were also focal parts of the spectacle. The decision to execute an offender at the scene of their crime lay in the hands of the central court judges who specified the date, time and location at which the sentence would be carried out. However, they stipulated that it was the responsibility of the local legal authorities, namely the sheriffs, to carry it out and thus this section will also explore how they too shaped the executions in practice. The third part of this study will examine the multitude of public reactions these events could generate. Several of the locations chosen to conduct the proceedings had not witnessed a similar event in living memory and its prospect caused varied responses from curiosity to outright disdain. There was correspondence sent to Home Office officials, who were responsible for decision-making in the pardoning process, petitioning against the executions. A reading of these sources reveals a certain level of contempt on the part of the authors at the prospect of their local areas being sullied by association with the public execution. Again, it is not the argument here that these events served as a successful deterrent from the commission of crime. However, these negative reactions to them added to their propensity to disrupt the localities and to serve as a reminder of the long arm of the law.

7 The final section of the study will provide an in-depth exploration of the final crime scene execution in Scotland in 1841. Railway labourers Patrick Redding and Dennis Doolan were sentenced to be executed at Crosshill, near Glasgow, for the murder of fellow railwayman John Green. The case attracted wide-spread public attention and their execution was replete with the hallmarks of the spectacle including the lengthy procession to the gallows and an immense execution crowd. However, their case was the final example of an execution at the scene of the crime in Scotland, and thus this section will end by offering some potential explanations for the decline and cessation of the punishment. It will also seek to contextualise the disappearance of crime scene executions in Scotland within the wider public debates in Britain over the implementation of the death sentence and the merits of public punishment. 


\section{Examining the Drivers behind Crime Scene Executions}

Between 1801 and 1841 there were thirty-seven offenders hanged at the scene of their crime. Overall this averaged at less than one case per year, but these cases accounted for 16 percent of the total 238 executions in Scotland in this period, and were an important and distinct Scottish response to the rising number of capital convictions in Britain in the early nineteenth century. The opening section of this study will question the drivers that prompted the judicial decision to utilise this penal option that had not been used in Scotland to a similar extent since the mid-eighteenth century. In terms of the method of analysis adopted here, it is important to note that there was no one factor that led to these executions. Instead they were prompted by numerous drivers. There were discernible similarities dwelled upon in some cases such as the youth of the offenders or the believed prevalence of the crime they had committed and thus there is some scope for a more statistical causal analysis. However, the study weaves its examination of factors such as age, gender, location and offence committed into a closer reading, and more qualitative analysis, of certain cases that reflected wider judicial and public concerns over crime to offer potential explanations for the use of crime scene executions.

Following the New Year festivities in Edinburgh in 1811 it was reported that "a gang of ferocious banditti armed with bludgeons [had] infested some of the leading streets of this metropolis", beating and robbing people and murdering one man. Those involved were described as "idle apprentice boys" all of whom were between 13 and 18 years of age. Three of their number, Hugh MacDonald, Neil Sutherland and Hugh Mackintosh, were tried before the High Court and capitally convicted for several counts of robbery with Mackintosh additionally found guilty of murder. They were sentenced to be executed on Edinburgh's High Street opposite Stamp Office Close, the scene of the murder. ${ }^{9}$ The case attracted the attention of senior legal authorities in Scotland and England with the Lord Justice Clerk, David Boyle, reporting to the Secretary of State, Richard Ryder, that the alarming nature of the crimes meant that the full weight of the law should take its course. ${ }^{10}$ It is important to acknowledge here that this case occurred at a time when fears over collective crowds committing crime had long been established and in some ways became even more pronounced in the early nineteenth century. ${ }^{11}$ The Aberdeen Journal reported at length upon the execution but reminded its readers that the death of these young men was intended as a dreadful example to be remembered for years to come and stated that this was the only justification for such a strong measure. ${ }^{12}$ However, the above case marked a watershed in Scotland's use of crime scene hangings in the early nineteenth century.

Table one demonstrates that, of the total thirty-seven cases, sixteen occurred between 1810 and 1819 and a further nine in the 1820s. This concentrated use of the penal option coincided with a marked increase in capital convictions more generally, as the figure rose from 59 offenders sentenced to death between 1800 and 1809 to 117 between 1810 and 1819 and to 174 in the 1820s. In turn the number of offenders executed between 1810 and 1819 doubled from 37 to 73 compared to the previous decade and rose to 81 in the 1820s. Despite the rise in capital convictions, these figures demonstrate that the proportion of offenders subsequently executed remained stable and slightly declined in the 1820 s. However, within the increasing space dedicated to crime reporting in the newspapers, there were calls for some further severity to quell the unprecedented numbers facing the 
hangman's noose. At least three quarters of the malefactors executed at the scene of their crimes were under the age of thirty with the highest number concentrated between eighteen and twenty-five years of age. While the prevalence of this age group is reflective of their dominance in the wider crime statistics in this period, the youth of the offenders was a key theme dwelled upon in the courts and in the press, as demonstrated in the above case. ${ }^{13}$

Table One : Crime Scene Executions in Scotland 1801-1841.

\begin{tabular}{|l|l|l|l|l|}
\hline Date & \multicolumn{2}{|l|}{ Type of Offence } & Total \\
& \multicolumn{2}{|l|}{ Murder Property Rape } & \\
\hline $1801-1809$ & 2 & 1 & 0 & 3 \\
\hline $1810-1819$ & 5 & 11 & 0 & 16 \\
\hline $1820-1829$ & 6 & 3 & 0 & 9 \\
\hline $1830-1839$ & 5 & 1 & 1 & 7 \\
\hline $1840-1841$ & 2 & 0 & 0 & 2 \\
\hline Total & 20 & 16 & 1 & 37 \\
\hline
\end{tabular}

SOURCE : Figures compiled using the Justiciary Court minute books.

11 An additional area to examine when questioning the concentrated use of crime scene executions is the judicial voice, as it was the judges who passed the death sentence. Following the 1672 Courts Act in Scotland, the High Court would sit in Edinburgh and twice a year, in Spring and in Autumn, two of the five Lords of Justiciary would travel to preside over the cases brought before the Northern, Western and Southern circuits. The published memoirs of Lord Henry Cockburn provide a rare insight into the experiences of a nineteenth-century Justiciary Court judge. He remarked that, when passing the death sentence, it was their duty to offer a practical exposition of the immediate and worldly effects of crime.$^{14}$ In the eighteenth and early nineteenth centuries, Scottish writers had provided several legal commentaries expounding the distinction of Scots law and highlighted the country's lesser recourse to the death sentence, especially when compared to its English counterpart. ${ }^{15}$ However, acknowledgements of Scotland's previous lesser recourse to the death sentence turned to lamentations of its increased use by the second decade of the nineteenth century which, in some cases, justified the judges' decision to execute the condemned at the scene of their crime.

This study has found that over the four decades under examination here, there were sixteen different judges involved in sentencing a crime scene execution. Around half of them were involved in only a single case. However, there were others who had sat upon the bench in up to six separate cases and employed similar rhetoric when ordering offenders to be executed at the scene of their crime. In the 1834 case of Mannes Swinney, Lord Meadowbank, who had been involved in four previous cases, proposed the measure to his fellow judges due to the aggravating nature of the offence. ${ }^{16}$ In addition, Lord David Boyle, who served as the Lord Justice Clerk, the most senior criminal judge, between 1811 
and 1841, sat upon the bench in at least thirteen of the cases. He often offered scathing lamentations over the nature of the crimes that he claimed had prompted his decision to order that offenders be executed at the scene of their crime. His prominence in these figures can also be explained by the fact that he predominantly sat at the High Court, where the sheer volume of business was greater. In addition, in Scotland criminals could be sent from areas that would ordinarily be covered by the circuit courts to be tried in Edinburgh in particularly heinous cases, including some of those examined here, which would also account for the Lord Justice Clerk being present on the bench. It is important to note here that, although individual judges were involved in multiple cases, in over two thirds of the total thirty-seven cases, these offenders were not the only malefactors capitally convicted at that court sitting. In turn, crime scene executions accounted for only a small proportion of the total death sentences these judges would pass over the course of their judicial career. Therefore, while there were some judges perhaps more inclined to use the penal option, there were aggravating circumstances in the cases that prompted them to sentence a crime scene execution.

Within the black catalogue of offences that carried a capital charge, the crime of murder had long since been chosen for exemplary punishment. Historically murderers could be subjected to sanguine execution spectacles involving both the pre-mortem and postmortem evisceration of the body. ${ }^{17}$ Crime scene executions could be used in heinous cases and in 1832 Sir Archibald Alison remarked that these executions were one of the only peculiarities available in modern practice. ${ }^{18}$ Thus their increased use in the early nineteenth century marked a re-introduction, as opposed to an introduction, into Scottish penal policy. Between 1801 and 184186 criminals were executed for murder. When questioning why twenty of their number suffered their fate at the scene of their crime, this study can offer some potential explanations. In the case of John McDonald and James Williamson Black, who were executed for the murder and robbery of William Muirhead on a highway in Coltbridge near Edinburgh in 1813, it was their chosen location of a public highway for the perpetration of the crime that had sealed their fate. The judges expressed astonishment at numerous recent cases of similar depravity in a country previously "distinguished for virtuous conduct". They added that it was their duty to "recur to those more striking and awful punishments which our law enjoins" and thus stipulated that Black and Muirhead would be hanged upon the spot where the body had been discovered.$^{19} \mathrm{~A}$ similar universal feeling of revulsion coupled with a desire to calm public anxiety led the Jedburgh Circuit Court to sentence Robert Scott to be executed upon the public road in Greenlaw where he had murdered two men in $1823 .{ }^{20}$ The judges in these cases were not necessarily motivated by the need for deterrence but rather a desire to be seen to punish offences of this nature more harshly through the use of crime scene executions.

In addition, to murders perpetrated upon the highways against strangers, there were also cases where the condemned had murdered someone close to them such as a spouse or a colleague. Again, while there were other similar cases where those convicted were executed at the "common place", certain circumstances in the following cases, coupled with the increased use of crime scene executions more widely, sealed their fate. In turn the locations chosen for their executions had the potential to have an even greater effect upon both the condemned and the crowd due to their spatial significance to the offender's previous life. In 1830 John Henderson was convicted of the murder of his employer James Millie, a handloom weaver in Cupar, by beating him to death with a 
hammer. He concealed the body for a time and forged deposits and bank receipts in his name. Lord Mackenzie labelled the murder as cruel and contrary to the relationship of trust between an employer and his apprentice. Henderson's execution outside the nearby Cupar jail was a novelty in the area which had not witnessed a similar spectacle since $1743 .{ }^{21}$ Although the judges stipulated the locations at which public hangings would occur, it was often the local authorities, namely the sheriffs, who decided upon the spatially specific spots to erect the gibbet. Following his conviction for the murder of his wife in 1804, Duncan MacArthur was sentenced to be executed upon the banks of Crinan Canal and the Sheriff Depute of Argyle ordered that he be hanged opposite his own home where the murder had occurred..$^{22}$ Similarly, when John Gibson was executed for murder in Hawick in 1814 the gibbet was purposefully constructed on a green opposite his house where he had stabbed his wife to death. ${ }^{23}$

The remaining offenders chosen for exemplary marking out were comprised of people who had committed serious property offences. Donnachie demonstrated that, within the overall number of criminal investigations, property crimes rose from making up slightly more than half the total number in 1810 to 75 percent by $1830 .^{24}$ The parliamentary returns for Scotland available for this period also reinforced how the overwhelming majority of those committed for trials had committed property offences..$^{25}$ Of the sixteen cases where property offenders were ordered to be executed at the scene of their crime, eleven occurred between 1810 and 1819. A potential explanation for this concentration in cases is discernible if we link them to the wider patterns of capital punishment. Capital convictions for property crimes more than doubled from 41 between 1801 and 1809 to 98 between 1810 and 1819. The decade between 1810 and 1819 saw 59 offenders executed 60 percent of those capitally convicted - compared to 53 percent in the previous decade and 44 percent in the 1820s. Most of these malefactors, including fifteen of the sixteen property offenders executed at the scene of their crime, had been tried and convicted in Scotland's central belt before the High Court in Edinburgh or the Western Circuit, which included the rapidly-developing Glasgow. This reinforces the centre-periphery dichotomy highlighted by King and Ward in their recent study of the regional variations in the implementation of capital punishment for property offences. ${ }^{26}$ In turn, it supports the argument here that crime scene hangings were used to mark out certain malefactors for exemplary punishment at a peak time of executions more generally.

Although nineteenth-century Scottish crime has not received the same level of historical attention as experiences south of the border, Kilday has highlighted that fears over a robbery epidemic were similarly evident in Scotland as in England, despite much lower numbers of prosecuted cases. ${ }^{27}$ The current study explores this argument in relation to its causal analysis of the increase in crime scene executions. Of the total sixteen crime scene executions for property offences, thirteen of the criminals had been convicted of robbery. The public discourse surrounding the case of Thomas Kelly and Henry o'Neil, who were executed in the parish of St Cuthbert's in December 1814 for three acts of highway robbery, embodied the contemporary concern over the believed prevalence of the crime. During their trial the Lord Justice Clerk lamented that the offence was being perpetrated to an extent "unknown formerly in this part of the United Kingdom". ${ }^{28}$ In England, robbery had previously been used as an indicator of the prevalence of crime. ${ }^{29}$ Comparatively, in Scotland, it was not until the increase in capital convictions for the crime in the early nineteenth century that the offence began to permeate Scottish crime reporting. When detailing the case of Kelly and O'Neil, the Caledonian Mercury stated that, 
to enact the most vigorous justice possible, the High Court sentenced them to be executed on the spot where they had committed the final robbery. ${ }^{30}$ The location chosen for the perpetration of the crime in several cases was public roads and thus the carrying out of executions on the same spots was intended to demonstrate the wide reach of the law. In turn, they often required lengthy processions and could take a whole day which serves to further demonstrate the willingness of the authorities to deviate from more modern execution practices to correct what the Scots Magazine called the "loose manners of the time" regarding the crime of robbery. ${ }^{31}$

Alongside the public anxiety over robberies perpetrated upon roads, there was also a contemporary concern about violent property offences committed in more domestic spaces. Of the total thirteen offenders executed at the scene of their crime for robbery, in five of the cases the condemned had been additionally charged with the crime of stouthrief. In the early nineteenth century, the crime could be charged synonymously with robberies that involved the use of violence in a dwelling place. In October 1817 three men were executed in Greenock following their conviction for breaking into the house of Robert Morris. They bound him, stole a quantity of money and clothes and raped his sister-in-law and a female servant. ${ }^{32}$ The execution of three offenders at the same time for the same crime was unprecedented in eighteenth-century Scotland. However, this case, and the previously discussed case of MacDonald, Mackintosh and Sutherland, was one of a few examples in the first third of the nineteenth century where the measure was deemed to be necessary due to the nature of their crimes. From a legal perspective, crime scene executions were utilised, and justified, as a means of stemming the unprecedented number of Scottish criminals facing a death sentence. However, to further explore their capacity to act as a stark reminder of the long arm of the law, this study will now examine how these events were shaped in practice and will explore the multitude of reactions they had the power to generate.

\section{Shaping the Spectacle}

18 The theatre of the gallows involved numerous actors from the authorities responsible for carrying out the death sentence to the condemned criminals and the crowd who attended to see the spectacle unfold. The eighteenth and nineteenth centuries have been the subject of particularly rich analyses of the use of capital punishment in Western Europe and studies have demonstrated that the period was one of debate and development in the carrying out of the death sentence. ${ }^{33}$ Within this, the practicalities of public executions, such as their locations, were gradually amended and changes were made to traditional elements of the scaffold ritual, including the procession to the gallows. In addition, historians including Gatrell and McGowen have respectively traced a discernible shift in responses to the spectacle on the part of the authorities and the crowd. ${ }^{34}$ It is the intention here to contextualise Scotland's use of crime scene executions within this wider narrative of the changing nature of capital punishment in the early nineteenth century.

By the turn of the nineteenth century, public executions in Scotland, as in England, were predominantly carried out at an established "common place". Prior to 1785 in Edinburgh this had been the Grassmarket, a busy area of the city's old Town, but was moved closer to the old Tolbooth to avoid what the Caledonian Mercury called "the disagreeable ceremony of walking from the prison to the former place of execution". ${ }^{35}$ Similarly, executions at Tyburn were abolished in favour of staging London's hangings outside of 
Newgate prison in 1783. In Scotland's circuit towns and cities executions had been conducted at locations which were outside of urban centres, such as the Gallows Hill in Aberdeen or the Burgh Muir of Perth, but they gradually moved closer to the jails by the late eighteenth century. Devereaux charted similar moves from urban peripheries to more central locations in some English towns in the same period. ${ }^{36}$ A key element of public executions in this period was the procession to the gallows, to quote Dr Samuel Johnson, "the public was gratified by a procession, the criminal supported by it". ${ }^{37}$ However, it was criticisms of this part of the spectacle that had factored into decisions to move the location of the "common place". ${ }^{38}$ Despite this, in both countries this shift was a gradual one and this, coupled with the re-introduction of crime scene executions in early nineteenth-century Scotland, meant that the eventual disappearance of the procession was not a pattern of uniform or uninterrupted decline.

Poole demonstrated that the standardisation of execution practices in England after 1783 was not driven by one central policy and that the processional culture persisted for some time thereafter, even on the doorstep of the capital. ${ }^{39}$ This was similarly the case in Scotland, but particularly so in executions at the scene of the crime where it was evident that, rather than solely being logistically necessary, the procession was a focal part of the whole spectacle. For example, Moses McDonald's procession to the gallows in Greenock took four hours and involved the criminal and his family as well as officials including the sheriff, the magistrates, the town council and the local clergy, and was made more stark as the town had not witnessed a similar event in living memory. ${ }^{40}$ The importance of the procession was not only evident during executions in areas that were unaccustomed to the execution spectacle, it also proved to be a focal attraction in larger cities such as Edinburgh. McDonald and Black's two-mile procession from the Tolbooth to the scene of their crime in Coltbridge took three hours. They were placed in a cart and taken through the Lawnmarket and the city's Old Town before passing Princes Street, which was at the heart of the more cosmopolitan New Town, before arriving at the scene of the murder. The whole journey was guarded by 200 men from the $7^{\text {th }}$ Dragoon. It was reported that the concourse of spectators was immense along the entire route with every possible view taken. Furthermore, as per the stipulations of the 1752 Murder Act, they had been sentenced to the post-mortem punishment of dissection. When their bodies were cut down they were put back onto the cart and "with the view of impressing the minds of the spectators with more awe" they were conveyed, uncovered, to Edinburgh University for dissection by Dr Alexander Monro, the Professor of Anatomy. ${ }^{41}$

21 When an offender was ordered to be executed at the scene of their crime the judges would stipulate the various steps of their journey from the place of sentencing to the place of execution. It was often the case that these locations were in different areas of jurisdiction and thus the procession to the scaffold involved the legal procedure of handing over the criminal, and the responsibility for seeing their sentence enacted, from one set of local authorities to another and this served to add further ceremony to the event. John Worthington had been condemned in Edinburgh in 1815 for three robberies he had committed upon a road leading out of Kilmarnock. He was sentenced to be transmitted to Glasgow, then to Lanark and finally to Ayr to be detained then taken to a convenient place near Symington Tollbar, situated on the highway between Kilmarnock and Monkton, and hanged. ${ }^{42}$ On the day of his execution Worthington was handcuffed to a cart and accompanied by the Sheriff of Ayr who travelled as part of the procession in a coach drawn by four horses as far as Flockbridge where he handed him over to the Sheriff 
of Renfrew who then escorted him to the place of execution. The whole proceedings were heavily guarded by a troop of cavalry and proved to be a lengthy procedure rich in the symbolism of both local and national justice. ${ }^{43}$

Due to the gradual shift of the "common place" of execution to more central locations that were closer to the places of confinement, and the reduced need for lengthy scaffold processions, the times at which executions were to be carried out began to change in the early nineteenth century. In Edinburgh in 1819 the time specified changed from between two and four in the afternoon to between eight and ten in the morning. The same alteration occurred in Glasgow in the 1820s and in this sense Scottish execution practices were comparable to those in England. ${ }^{44}$ In conducting the executions earlier, the authorities were attempting to prevent them taking up a whole day and were limiting the opportunity for excessive drinking prior to the crowd's arrival at the foot of the gallows, which had previously been facilitated by the later time, the closure of local businesses, and people having the day off work for the occasion. ${ }^{45}$ However, due to the need for a procession to the scaffold, crime scene executions were sentenced to take place between two and four in the afternoon and often required a whole day, thus disrupting the areas in which they were held. When Mark Devlin was executed in Dundee in 1835, the High Street was completely shut down due to the volume of people lining the streets from an early hour. ${ }^{46}$ Similarly, a crowd of up to 15,000 had gathered from all over the county of Fife for the execution of John Henderson in Cupar in 1830 which meant that shops were closed, businesses disrupted and the collection of the harvest was at a complete standstill for miles around. ${ }^{47}$ The execution of William Perrie in Paisley in 1837 prompted a whole day of festivities. There were reports that the roads leading in and out of the town were "thronged till night fall with crowds." An article in the Morning Advertiser remarked with cynicism that the people spent the day "drunk from the contemplation of the melancholy spectacle." ${ }^{48}$ The implication being that the execution had been an occasion for drunken revelry, a criticism that had been levelled at the public execution spectacle since the eighteenth century.

Another important element of the execution ritual was the construction of the scaffold. By the 1830s there were no permanent gallows at Edinburgh's "common place" of execution at the Lawnmarket. Instead they were usually constructed the night before a scheduled execution and then quickly removed thereafter as was the case in other circuit cities. Devereaux argues that, following the move of executions in London to outside Newgate, the gallows were intended to be a short and sharp intrusion upon the urban space and upon people's psyche. The swift introduction and removal of the gallows on an execution day was intended to make the whole display more shocking to the observer. ${ }^{49}$ Logistically crime scene executions were similar in that they involved the construction of temporary gallows. However, in some cases this served to add more intrigue in areas not accustomed to the spectacle and could attract a considerable crowd. For example, a large concourse of spectators gathered at one o'clock in the morning to watch the construction of the scaffold in Dundee for the execution of Mark Devlin, who had been condemned for raping a child, in $1835 .^{50}$

\section{Responses to Crime Scene Executions}

24 A key component of the ability of crime scene executions to act as an effective penal option was the behaviour of the criminal and the watching crowd. It had long been a 
hallmark of British gallows culture to allow malefactors to address the crowd in their last dying speech. In the cases examined here, some criminals spoke only briefly to confess to their crimes. The Caledonian Mercury stated that the suitable display of contrition shown by John Westwater in 1806 ideally met the object of his execution at the scene of his crime. ${ }^{51}$ In other cases the criminals did not confess to their crimes but they claimed to accept their fate and asked that the crowd join them in praying for God's mercy. Due to the familiarity of some crime scene execution locations to an offender's previous life, some criminals were overcome with more shame that their relatives should witness their execution than the death sentence itself. For example, in 1828 Francis Cockburn asked that the blinds of the chaise conveying him to his execution in Camelon be drawn so he could not see his old acquaintances..$^{52}$ In terms of the reactions of the crowds gathered at the gallows foot, Laqueur wrote of a "carnivalesque" crowd "unconcerned with serious state theatre and unaffected by its efforts". ${ }^{53}$ An often-cited criticism of execution spectacles in this period was the concern that they encouraged drunken revelry which undermined the solemn carrying out of justice.$^{54}$ This was certainly a criticism levelled at the execution of William Perrie due to the drunken behaviour of the crowd in Paisley. However, Gatrell argued that by the early nineteenth century, while older curiosities surrounding scaffold horrors were still evident, they came to be justified as a "valued element in the sympathetic sensibility". ${ }^{55}$ An exploration of the contrasting responses to the intrusion of the public execution into local areas unaccustomed to the spectacle is crucial to our understanding of their capacity to act an effective penal option.

One of the prevalent motivations in sentencing offenders to be executed at the scene of their crime was to send out a stark reminder of the long arm of the law, especially in the more remote areas of Scotland. In the early nineteenth century, the main central belt cities of Edinburgh and Glasgow accounted for a large proportion of the total number of capital convictions. While executions may not have occurred as regularly as they did in some of the bigger English cities, there could be up to five or six in a year making them a semi-regular spectacle. Within this, although twenty-six of the total thirty-seven cases examined here occurred following trials in Edinburgh or before the Western Circuit, they had national ramifications due to the locations at which they were carried out, which could be miles away from the place of sentencing. In several cases the executions were the first to occur in the area in decades or even beyond living memory or record and they had the potential to produce a range of reactions from the local inhabitants in the weeks between sentencing and the date of execution. ${ }^{56}$ In some cases, such as that of Ralph Woodness in Linlithgow in 1819, the crowd's attendance was driven by curiosity due to the rarity of the event. ${ }^{57}$ In others the close proximity of the executions to the places where the condemned had lived and worked could evoke a sympathetic reaction from the crowd. Alternatively, there was evidence that in some areas the prospect of a public execution produced feelings of anxiety due to a belief that the spectacle would bring shame to an area previously unsullied by the last punishment of the law.

The public feeling in Greenlaw at the time of the execution of Mannes Swinney in 1834 was one of "great and unpleasant agitation" due to the fact that the town was proud of its having no tradition as an execution location. ${ }^{58}$ When Thomas McNair was convicted of robbing a man on a road in Falkirk in 1811 many of the town's respectable inhabitants signed a petition for mercy to prevent the hosting of the execution there. ${ }^{59}$ However, it was evident that in this petition, as in others that were sent to the Home Office regarding crime scene executions, it was not necessarily the fate of the condemned person that the 
writers were concerned about. Instead they argued that the executions would be detrimental to the local area and asked for mercy for the community. Following the conviction of Moses McDonald for housebreaking and theft in 1812, he was sentenced to be hanged near the scene of the crime in Greenock. The magistrates of the town sent a petition to London stating their firm conviction that "every beneficial consequence to that community [Greenock] which could be contemplated by the result of a public execution...will be equally, nay preferably, prompted by a commutation of his punishment from death to transportation" ${ }^{60}$ A similar sentiment was echoed in petitions regarding the case of Margaret Shuttleworth in 1821. In the weeks between her sentencing and execution for the murder of her husband, respectable gentlemen from the town of Montrose petitioned for a commutation of the sentence to spare the inhabitants from the horrid exhibition of a public hanging, especially that of a female. The execution of a woman was a rare event in Scotland, especially by the early nineteenth century. ${ }^{61}$ In turn, there were only two women executed at the scene of their crime in this period, both for murder. Due to their relative rarity, the executions of women created great public interest. ${ }^{62}$ However, newspaper reports of Shuttleworth's execution observed that many of the town's respectable citizens had left for the occasion. ${ }^{63}$ Again her case demonstrated that people were not necessarily sympathetic to her plight as she was a known drunk who often quarrelled with her late husband. Instead they were more concerned with the potential shame of the town hosting a public execution.

Early on the morning of William Thomson's execution on the road leading into Dalkeith, where he had robbed George Dickson in 1827, a large crowd had assembled. However, it was remarked that most had travelled from outside of the town. In Edinburgh, a crowd had gathered at the jail to see him brought out and followed in procession. In contrast the inhabitants of Dalkeith "regarding the exhibition with feelings of horror and detestation, a similar scene not having been witnessed there for centuries, shut their places of business and manifested every indication of regret at their respectable town having been subjected to such degradation." ${ }^{64}$ In this case the question of whether the motivation of making a deep impression upon the town was achieved is more complex. In one sense the inhabitants were so disgusted as to openly protest it, however it is unclear how many of them still attended the execution. In contrast, the crowd in Edinburgh, perhaps more accustomed to public executions, showed a keen interest in the whole spectacle, particularly the novelty of a lengthy scaffold procession. What is clear is that Thomson's execution clearly impacted negatively upon the daily lives of Dalkeith's inhabitants and acted as a stark presentation of the criminal justice system and thus made some impression upon them, even if this was annoyance.

When faced with the prospect of a public execution, some areas took the precaution of arranging additional security to guard the proceedings. John Westwater's execution in Kinghorn in 1806 was guarded by the Kirkcudbright militia who had been transported in from Leith for the occasion. ${ }^{65}$ Extra guards were also brought in for the hanging of Arthur Wood in Dundee in 1839 due to a suspicion of unrest. However, reports of the execution described a sympathetic yet solemn scene. ${ }^{66}$ Similarly, due to a suspicion that a rescue attempt would be made when Thomas McNair was sentenced to hang in Falkirk, 500 infantrymen and three troops of cavalry were on standby. However, it was reported that they were not all required as the town's principal inhabitants had formed themselves into a guard and patrolled the streets. They had taken this action due to the feelings of unease caused by the large influx of outsiders for the event. ${ }^{67}$ Although there were no reported 
instances of serious unrest or attempts to prevent the executions taking place among the cases examined in this article, the contemporary fear that there would be serves to reinforce the argument that the courts were willing to risk this unrest in their pursuit of inflicting some further severity to the death sentence.

Despite the varied responses to the prospect of a crime scene hanging, reports of the executions themselves often described a more solemn atmosphere when it came to the point in the spectacle when the offender mounted the scaffold. The newspapers may have been more inclined to report a scene of contrition on the part of the condemned and repeatedly used words such as solemn and orderly to describe the behaviour of the crowd meaning we must be cautious when taking their reports entirely at face value. However, they do offer some valuable insight into the execution scene. Details of the crowd's behaviour offered in the following cases serve to support the argument made by historians that, despite a continued curiosity over the execution ritual, the prevailing feelings reported in the newspapers were those of sympathy and solemnity rather than the taking of pleasure at the suffering of others ${ }^{68}$ In the case of Robert Scott, despite a universal feeling of disgust towards the brutal murders he had committed, when he mounted the scaffold the crowd joined him in singing psalms. ${ }^{69}$ It was reported that the calm resignation of David Balfour to his fate in Dundee in 1826 rendered the large crowd almost silent. ${ }^{70} \mathrm{~A}$ similar "death-like stillness" among the spectators was described at the execution of Margaret Wishart in Forfar in 1827 and continued until her body was cut down 45 minutes later. ${ }^{71}$ In addition to a solemn atmosphere among the execution crowds, there was also evidence of sympathy for the criminal. When Ralph Woodness was hanged in Linlithgow "his boyish aspect and the weakness of his bodily frame meant a deep commiseration was expressed by the spectators". The article added that his career of crime was forgotten and only the feeling of sympathy persisted for the trembling youth. ${ }^{72}$ These reports demonstrate that crime scene executions, as with public executions more generally in this period, had the potential to strike a chord with many in the watching crowd and served as a stark reminder to the crowd of the reward for crime whether they had initially attended through excitement, curiosity or even with some reservation.

\section{The Disappearance of Crime Scene Executions}

Patrick Redding, Dennis Doolan and James Hickie were tried before the Glasgow Circuit Court in April 1841 for the murder of John Green the previous December and their case was to be the final example of a crime scene execution in Scotland. Green was a ganger, the leader of the railway labourers, on the building of the Edinburgh to Glasgow railway line and two days after he had taken charge of the gang, which included the accused men, he sacked Doolan. The court heard how they were angered and how Doolan had threatened "I'll leave him [Green] so that he will not sack any-body again". The three men waited for Green on the railway at Crosshill and assaulted him with an iron poker, which fractured his skull, before they beat him to death. ${ }^{73}$ Prior to the commencing of their trial the greatest exertions had been made by their fellow Irish labourers and others in their Glasgow neighbourhood to obtain first-rate defence counsel for them. During the trial, each of the accused blamed the others but the jury unanimously found Doolan and Redding guilty of murder, and by a plurality of voices found Hickie guilty only "art and part" of the murder but recommended him to mercy. ${ }^{74} \mathrm{He}$ was later pardoned on 
condition of transportation. In passing sentence, the judges Boyle and Moncrieff stated that, to make an example of the offenders, they were sentenced to be carried back to Glasgow jail to remain until 14 May 1841 when they were to be taken to Crosshill and hanged at the scene of the murder. ${ }^{75}$

31 What is clear from the trial proceedings and the detailed newspaper coverage of the case is that the criminals were suitably admonished, as were other murderers, for the heinous nature of their offence. However, in this case the criminals had received some local support and there was a believed need to make a stark statement to the large number of railway labourers in the area. These labourers included Irish migrants who had travelled to Glasgow to work on the construction of the railways and, as the 1840s progressed, the concerns raised over the influx of Irish migrants during the Potato Famine intensified. ${ }^{76}$ These factors combined likely prompted the decision to execute Doolan and Redding at this spatially significant location. Similarity can be found here with the final crime scene execution in England in the Somerset village of Kenn in 1830, when three men were convicted for the crime of incendiarism, the burning of property. Poole demonstrated that the execution came at a time of social protest and was conducted at the scene of the crime to protect the judicial necessity of informing in the rural community and thus the judicial cavalcade that accompanied the criminals to the scaffold was particularly extravagant. ${ }^{77}$ The execution of Doolan and Redding was intended as a similar demonstration of the power of the criminal justice system. It was thoroughly planned to ensure that as many people as possible witnessed the spectacle between Glasgow and Crosshill and it had required many more guards than would have been necessary if the execution had occurred at Glasgow's "common place" of execution in Jail Square. Many crime scene executions were justified due to their spatial significance but in the case of Doolan and Redding, as in the 1830 English case, it was also targeted towards a specific audience and thus the authorities were clearly willing to forgo concerns for cost and security to make a bold statement.

On the day before the execution the gallows were partly constructed outside of the prison in Glasgow which caused a considerable degree of interest. A large crowd then followed as they were taken in procession through the city to the place of execution. They were then guarded overnight by an infantry guard. ${ }^{78}$ The following day the prisoners emerged from the prison at eight in the morning to begin the three-mile procession to Crosshill. They were purposefully seated high up in a carriage so they could be seen by the crowd as they passed through Glasgow's busy city centre. The procession included the executioner, the sheriff, the City Marshall, the Lord Provost and the magistrates and, as the authorities went to great lengths to ensure the whole passed without incident, it was guarded by a troop of 200 cavalrymen and 700 infantrymen..$^{79}$ The crowd gathered to witness the execution was described as being greater in size than any other congregation in the Glasgow area in living memory. However, there were no reported incidents of unrest. Instead the multitude gathered was described as being "awe-struck and compelled to acquiesce to the justice of the sentence" ${ }^{80}$ Furthermore, in reference to the railway labourers, one article stated that this "dreadful but so imperiously required" example was intended to have a profound effect upon the "most lawless and obdurate dispositions". ${ }^{81}$ Whether this aim was achieved is more complex as a broadside detailing the execution observed that none of the railway labourers were at work that day, nor did many of them attend the spectacle. It added that "they had resolved to stay away to show their contempt for the insult which they conceived had been offered to them in bringing the 
execution to Crosshill." 82 Therefore, similar to previous cases where the local inhabitants had refused to attend crime scene executions to show their feelings against them, it is clear that the spectacle had an effect upon the area, and to some extent the railway labourers, as desired by the authorities whether this was disruption, anxiety or disdain.

Following the case of Doolan and Redding there were no more offenders executed at the scene of their crime in Scotland and thus the final part of this article will offer some potential explanations for the disappearance of the practice. The study has demonstrated that the early nineteenth century was a period of discussion and debate over the merits of public punishment and that crime scene executions marked a distinct Scottish response to this British problem. Despite the contemporary justification that these executions were a necessary addition to the death sentence in the face of an increase in capital convictions overall, it is the argument here that the cessation of crime scene executions cannot be separated from the broader British movement to marginalise public punishments, which eventually culminated in the move of executions behind the prison walls in 1868 .

When investigating capital convictions in London and Middlesex, Emsley shows that they markedly increased following the end of the Napoleonic Wars, but the number of executions did not drastically increase. He argued that this widening gap between capital convictions and executions, while coming at a time when the Bloody Code faced increasing criticism by reformers, may also have been recognition, on the part of the authorities, that it would not be acceptable to execute so many individuals. ${ }^{83}$ In a similar vein, Gatrell highlights that in 1785 , during the crime wave of the 1780s, 56 percent of capitally convicted offenders were executed but argued that this proportion could not be sustained in the $1820 \mathrm{~s}^{84}$ Thus he cited the rising death sentences of the early nineteenth century as a primary reason why "the system unravelled itself and became unworkable". ${ }^{85}$ Comparatively, in Scotland in the first four decades of the nineteenth century, the proportion of capitally convicted offenders who were executed was consistently around 60 percent. ${ }^{86}$ Despite this proportional consistency, an examination of the disappearance of crime scene executions does demonstrate that the Scottish experience of capital punishment in this period can provide some reinforcement to the wider British narrative.

One of the arguments made in this article is that the increase in the number of offenders executed in Scotland, which had doubled between the first and second decades of the nineteenth century and had risen further in the 1820s, coincided with the increased and concentrated use of crime scene executions. However, the total number of executions in the 1830s almost halved compared to the figure for the 1820s, which may help to explain why crime scene executions also began to diminish. Furthermore, by the 1830 s murder was the predominant crime sending offenders to the scaffold as property offenders increasingly received the non-capital punishments of transportation and prison sentences, a fact noted by Riggs in his investigation of prosecution decisions and the restriction of the charges in cases of property crime.$^{87}$ Compared to the figure for murder, which had remained steady in the three decades between the 1810 s and the 1830 s, following the peak decade of crime scene executions for property offences between 1810 and 1819, death sentences for this type of crime notably declined in the 1820s. By 1841, the end of the period under investigation here, Lord Cockburn noted that in cases of rape and robbery recently brought before the Glasgow Circuit Court, despite the fact that the crimes were clearly proven, "such is the prevailing aversion to capital punishment...these horrid culprits were only transported" ${ }^{88}$ Furthermore, while there were still discussions 
over the believed prevalence of certain crimes within the newspapers, their attention increasingly turned towards debates over the reform of the capital code which was contrary to the previous calls for more severity which had justified the use of crime scene executions.

In addition to the developments in the implementation of capital punishment, we must also consider the importance of the changes that occurred to the carrying out of the death sentence in practice when questioning the disappearance of crime scene executions. As noted above, the period between the late eighteenth and early nineteenth century witnessed focal changes to the public execution spectacle in Britain, notably the locations at which they were carried out. By their very nature, crime scene executions deviated from the "common place" and were the exception rather than the rule. Although they were contrary to more modern concerns for efficiency, they had previously been justified in Scotland due to a contemporary belief that some further severity was required to the punishment of death. However, by the 1830s and early 1840 s the sheer number of executions in Scotland had notably decreased, despite the relative consistency in the proportion of capitally convicted offenders sent to the gallows. In this sense, Pratt's observation that the main body of opposition to public executions in the early nineteenth century was due to their potential to cause a distasteful scene, rather than the actual execution of offenders, is particularly relevant to the disappearance of crime scene executions in Scotland. ${ }^{89}$

Crime scene executions provided a spike in an otherwise long term decline in certain elements of gallows culture. In terms of their logistics, Poole argues that their cost was one reason for their decline more generally. ${ }^{90}$ In addition, the management of public executions had attracted unfavourable comment in eighteenth-century England and Scotland. ${ }^{91}$ Specific criticism had been levelled at lengthy crowd processions to the gallows which were increasingly viewed as being contrary to the solemn carrying out of justice. ${ }^{92}$ When discussing the eventual removal of executions to behind the prison walls in 1868 , Gatrell placed the move within the longer-term context of the changes that had occurred to capital punishment more widely in the previous three decades. He argued that the key reason for the change had been to exclude the crowd from the practice. ${ }^{93}$ Therefore, while concerns over crowd behaviour at public executions were not new, in the early nineteenth century they occurred at the same time as wider debates over the merits of public punishment and even the implementation of the death sentence which offers a further explanation for the disappearance of crime scene executions.

\section{Conclusion}

Crime scene executions had been a penal option in Scotland prior to the early nineteenth century but had been used on an infrequent basis following a concentration of cases in the mid-eighteenth century. However, there were thirty-seven criminals executed at the scene of their crime in the first four decades of the nineteenth century. Although this averaged at less than one per year and perhaps would not constitute a "panic" at face value, the contextualisation of these executions in this study demonstrated that their reintroduction in early nineteenth-century Scotland was explicitly linked to wider patterns in capital punishment. In addition, it presented a reverse trend to that found in England where this type of execution was an eighteenth-century feature that survived sporadically in the nineteenth century. ${ }^{94}$ While capital convictions increased north and 
south of the border, this study has identified a distinct Scottish response to this British problem. The proportion of capitally convicted offenders who were subsequently executed remained relatively stable in the first third of the nineteenth century in Scotland, as opposed to the widening of the gap between the numbers convicted and executed in England..$^{95}$ Therefore, despite the sheer number of executions remaining lower than in England, this led to an unprecedented number of criminals suffering the death sentence in Scotland and, within this, a development in the newspapers from lamenting the situation to calling for a solution to stem the problem.

A reading of judicial opinion when passing the death sentence and the contemporary public discourse that followed demonstrates that these calls were met by, and used to justify, the use of crime scene hangings. This study has not argued that these executions acted as a successful deterrent from crime. Instead it has explored throughout the importance of the desire of the authorities to inflict some greater form of punishment to the death sentence and has shown that, as the more sanguine spectacles of previous centuries had disappeared, crime scene executions remained one of the only surviving penal options. Within this, these executions were often targeted towards a specific crime or location. For example, robbery was very much a public concern in this period and executions for the crime accounted for thirteen of the total sixteen crime scene hangings for property offences. In the case studies discussed above, the locations chosen for the commission of the crimes, namely public roads, were crucial in the judge's decision to execute offenders at the scene of the crime to assuage public anxieties.

The locations chosen for crime scene executions were crucial to their ability to impact upon the areas at which they were carried out. In some cases, offenders went "home" to die, quite literally when the gallows were put up outside their houses, and marked a stark juxtaposition of their previous life and their lamentable fate. In others, the executions intruded into localities previously unsullied by association with the last punishment of the law and prompted a range of reactions from curiosity and a desire to participate in the whole spectacle to outright disdain and a refusal on the part of the locals to attend. Again, an important point made by this study was not that these executions served as the successful deterrent sought by the authorities in the face of rising numbers of capital convictions. Instead, the study has shown that they were a pervasive prospect whether they were revered or reviled and they certainly served as an exemplary demonstration of national justice being seen to be done at a local level. In turn, while their re-introduction and eventual decline were explicitly linked to wider trends in capital punishment, they present something of a spike in the wider long term dismantling of older forms of public punishment in Britain.

\section{BIBLIOGRAPHY}

References

Primary Sources 
National Archives Scotland, Edinburgh

Justiciary Court Records

JC8 High Court Minute Books Series E Folios 1 to 44.

JC11 North Circuit Minute Books Folios 44 to 88.

JC12 South Circuit Minute Books Folios 23 to 45.

JC13 West Circuit Minute Books Folios 31 to 82.

National Archives, Kew

Home Office Papers.

HO102 Home Office : Scotland Correspondence and Papers Folios 54 to 58.

HO104 Home Office : Scotland : Criminal Entry Books Folios 3 to 10.

Secondary Sources

Alison, A., Principles of the Criminal Law of Scotland, Edinburgh, William Blackwood, 1832.

Bennett, R., Capital Punishment and the Criminal Corpse in Scotland 1740 to 1834, Unpublished Doctoral Thesis, University of Leicester, 2016.

Boyle, M., Metropolitan Anxieties : On the Meaning of the Irish Catholic Adventure in Scotland, London, Routledge, 2011.

Chase, M., 1820 : Disorder and Stability in the United Kingdom, Manchester, Manchester University Press, 2013.

Cockburn, H., Circuit Journeys, Edinburgh, David Douglas, 1889.

Crowther, M.A., "Crime, Prosecution and Mercy : English Influence and Scottish Practice in the Early Nineteenth Century", in Connolly, S.J. (Ed.) Kingdom's United ? Great Britain and Ireland since 1500, Dublin, Four Courts Press, 1999, pp. 225-238.

Devereaux, S., "Recasting the Theatre of Execution : The Abolition of the Tyburn Ritual", Past and Present, 2009, 202, pp. 127-174.

Donnachie, I., "The Darker Side : A Speculative Survey of Scottish Crime During the First Half of the Nineteenth Century", Journal of the Economic and Social History of Scotland, 1995, 15, pp. 5-24.

Emsley, C., Crime and Society in England 1750-1900, (4 $4^{\text {th }}$ Edition), London, Routledge, 2013.

Evans, R.J., Rituals of Retribution ; Capital Punishment in Germany 1600-1987, Oxford, Oxford University Press, 1996.

Fielding, H., An Enquiry into the Causes of the Late Increase of Robbers, With Some Proposals for Remedying This Growing Evil, London, 1751.

Flanders, J., The Invention of Murder : How the Victorians Revelled in Death and Detection and Created Modern Crime, London, Harper Press, 2011.

Friedland, P., Seeing Justice Done: The Age of Spectacular Capital Punishment in France, Oxford, Oxford University Press, 2014.

Gatrell, V.A.C., The Hanging Tree ; Execution and the English People 1770-1868, Oxford, Oxford University Press, 1994.

Home, H., Statute Law of Scotland Abridged with Historical Notes, Edinburgh, 1757. 
Hume, D., Commentaries on the Law of Scotland Respecting Crimes Volumes 1 and 2, Edinburgh, Bell and Bradfute, 1819.

Kilday, A.M., "Contemplating the Evil Within : Examining Attitudes to Criminality in Scotland 1700-1840", in Lemmings, D. (Ed.) Crime, Courtrooms and the Public Sphere in Britain 1700-1850, Surrey, Ashgate, 2012, pp. 147-166.

Kilday, A.M., "Hell-Raising and Hair-Razing : Violent Robbery in Nineteenth-Century Scotland", Scottish Historical Review, 2013, 92, pp. 255-274.

King, P., Crime, Justice and Discretion in England 1740-1820, Oxford, Oxford University Press, 2000.

King, P., "Urbanisation, Rising Homicide Rates and the Geography of Lethal Violence in Scotland 1800-1860", History, 2011, 96, pp. 231-259.

King, P. \& Ward, R., "Rethinking the Bloody Code in Eighteenth-Century Britain : Capital Punishment at the Centre and on the Periphery", Past and Present, 2015, 228, pp. 159-205.

Knox, W.W.J. \& Thomas, L., "Homicide in Eighteenth-Century Scotland : Numbers and Theories", The Scottish Historical Review, 2015, 94, pp. 48-73.

Laqueur, T., "Crowds, Carnival and the State in English Executions, 1604-1868”, in Beier, A.L., Cannadine, D. \& Rosenheim, J.M. (Eds.), The First Modern Society ; Essays in English History in Honour of Lawrence Stone, Cambridge, Cambridge University Press, 1989, pp. 305-355.

Lemmings, D., "Negotiating Justice in the New Public Sphere : Crime, the Courts and the Press in Early Eighteenth-Century Britain", in Lemmings, D. (Ed.) Crime, Courtrooms and the Public Sphere in Britain 1700-1850, Surrey, Ashgate, 2012, pp. 119-145.

Linebaugh, P., The London Hanged : Crime and Civil Society in the Eighteenth Century, London, Penguin Press, 1991.

Louthian, J., The Form of Process before the Court of Justiciary in Scotland, Edinburgh, 1732.

McGowen, R., "Civilising Punishment : The End of the Public Execution in England", Journal of British Studies, 1994, 33, pp. 257-282.

McGowen, R., "Making Examples and the Crisis of Punishment in Mid-Eighteenth-Century England", in Lemmings, D., (Ed.) The British and their Laws in the Eighteenth Century, Woodbridge, Boydell Press, 2005, pp. 182-205.

Poole, S., “A Lasting and Salutary Warning : Incendiarism, Rural Order and England's Last Scene of Crime Execution", Rural History, 2008, 19, pp. 163-177.

Poole, S., "For the Benefit of Example : Crime Scene Executions in England, 1720-1830", in Ward, R. (Ed.) A Global History of Execution and the Criminal Corpse, Basingstoke, Palgrave, 2015, pp. 71-101. Pratt, J., Punishment and Civilisation, London, SAGE Publications, 2002.

Riggs, P.T., "Prosecutors, Juries, Judges and Punishment in Early Nineteenth-Century Scotland", Journal of Scottish Historical Studies, 2012, 32, pp. 166-189.

Ward, R., "Print Culture, Moral Panic, and the Administration of the Law : The London Crime Wave of 1744", Crime, History and Societies, 2012, 16, pp. 5-24.

Young, A.F., The Encyclopaedia of Scottish Executions, 1750-1963, Kent, Eric Dobby Publishing, 1998. Online Sources

British Library Newspaper Archive [http://www.britishnewspaperarchive.co.uk]

House of Commons Parliamentary Papers [http://parlipapers.chadwyck.co.uk] 
The Word on the Street [http://www.digital.nls.uk/broadsides]

\section{NOTES}

1. Caledonian Mercury, Monday 15 June 1801, p.3.

2. King (2011, pp.231-259); Donnachie (1995, pp.5-24).

3. Bennett (2016). An additional useful, but incomplete, survey is Young's Encyclopaedia of Scottish Executions. See Young (1998).

4. Poole (2015, p.76).

5. For studies of England see Emsley (2013, pp.265-267); (Gatrell, 1994, p.544). For a study of Scotland see Bennett (2016, p.64).

6. Crowther (1999, p.233).

7. Lemmings (2012, p.128).

8. Kilday (2012, p.159).

9. National Archives of Scotland, Edinburgh [hereafter NAS] JC8/8/266.

10. The National Archives, Kew [hereafter TNA] HO102/55/66.

11. Linebaugh (1991, pp.333-370); Chase (2013); Knox (2015, p.60).

12. Aberdeen Journal, Wednesday 29 April 1812, p.3.

13. See Donnachie (1995, p.20); Bennett (2016, pp.68-69).

14. Cockburn $(1889$, p.6).

15. See Louthian (1732); Home (1757); Hume (1819); Alison (1832).

16. Caledonian Mercury, Monday 14 April 1834, p.3.

17. For example, there were a handful of cases in the mid-eighteenth century of male murderers being sentenced to have a hand served from their bodies immediately prior to their execution. However, these cases were rare and disappeared after one sporadic case in 1765. See Bennett (2016, Ch.3). The 1752 Murder Act (25 Geo. II c.37) formally legislated for the post-mortem punishment of executed murderers but the penal option of dissection was removed by the 1832 Anatomy Act ( 2 \& 3 Will. IV c. 75). Hanging in chains remained a penal option until it was repealed by an act in 1834 ( 4 \& 5 Will. IV c. 26 ) but in practice the punishment had disappeared in Scotland by the late 1770s, apart from one isolated case in 1810 .

18. Hume (1819, p.279); Alison (1832, p.90).

19. NAS JC8/9/232; Scots Magazine, Monday 7 June 1813, pp.36-39.

20. NAS JC12/36/2.

21. NAS JC11/77/71; Caledonian Mercury, Saturday 2 October 1830, p.3.

22. NAS JC13/33/78.

23. Caledonian Mercury, Saturday 14 May 1814, p.3.

24. Donnachie (1995, pp.9-10).

25. Parliamentary Papers, Vol. XI (163) 1814-1815; Parliamentary Papers, Vol. XXXV (499) 1831-1832.

26. King \& Ward (2015).

27. Kilday (2013).

28. NAS JC8/11/10; Scots Magazine, Sunday 1 January 1815, p.31.

29. For a study of the London newspapers in the 1740s see Ward (2012, pp.5-24).

30. Caledonian Mercury, Thursday 26 January 1815, p.3.

31. Scots Magazine, Sunday 1 January 1815, p.31.

32. NAS JC8/12/301.

33. Gatrell (1994); Evans (1996); Spierenburg (1984); Friedland (2014).

34. Gatrell (1994, p.250); McGowen (1994, pp.259-265); id. (2005, p.202).

35. Caledonian Mercury, Wednesday 20 April 1785, p.3. 
36. Devereaux (2009, p.140).

37. Gatrell (1994, p.37).

38. For a widely-cited contemporary criticism see Fielding (1751, p.124).

39. Poole (2015, p.96).

40. Caledonian Mercury, Monday 8 June 1812, p.3.

41. Scots Magazine, Thursday 1 July 1813, pp.43-44.

42. NAS JC8/11/35.

43. Caledonian Mercury, Monday 20 February 1815, p.3.

44. Devereaux (2009, p.156).

45. For a discussion of the "carnivalesque" execution crowd, see Laqueur (1989).

46. Caledonian Mercury, Monday 1 June 1835, p.3.

47. Caledonian Mercury, Saturday 2 October 1830, p.3.

48. Morning Advertiser, Thursday 3 May 1838, p.1.

49. Devereaux (2009, p.156).

50. Caledonian Mercury, Monday 1 June 1835, p.3.

51. Caledonian Mercury, Monday 23 June 1806, p.3.

52. Aberdeen Journal, Wednesday 14 May 1828, p.4.

53. Laqueur (1989, p.332).

54. Fielding (1751, pp.121-127).

55. Gatrell (1994, p.250).

56. Note that the 1725 Disarming Act (11 Geo I c.26) stipulated that executions in Scotland could not be carried out within less than thirty days if the sentence was pronounced south of the River Forth and within less than forty days if pronounced north of the Forth. The 1752 Murder Act did not repeal this clause therefore all capitally convicted Scottish criminals had time to send petitions to London.

57. Caledonian Mercury, Monday 30 August 1819, p.3.

58. London Standard, Tuesday 8 April 1834, p.1.

59. TNA HO102/54/513.

60. TNA HO102/55/232.

61. Women made up a similarly low proportion of capitally convicted offenders in England. See King (2000, p.280).

62. Flanders (2011, p.166).

63. Morning Post, Wednesday 12 December 1821, p.3.

64. Caledonian Mercury, Saturday 3 March 1827, p.3.

65. Caledonian Mercury, Monday 23 June 1806, p.3.

66. Caledonian Mercury, Thursday 28 March 1839, p.3.

67. Caledonian Mercury, Saturday 28 December 1811, p.3.

68. See Gatrell (1994, p.250). Similarly, Friedland explored the correlation between a fascination with executions in France but a revolution in sensibilities which meant that taking pleasure from the event was deemed to be inhuman. See Friedland (2014, p.143).

69. Caledonian Mercury, Saturday 1 November 1823, p.4.

70. Caledonian Mercury, Monday 5 June 1826, p.3.

71. Caledonian Mercury, Saturday 23 June 1827, p.3.

72. Caledonian Mercury, Monday 30 August 1819, p.3.

73. NAS JC13/82/60.

74. Scottish juries consisted of fifteen members and a verdict could be returned with a majority decision. In addition, those accused of murder could be found guilty only of "art and part" and, while these cases were relatively rare, they still carried a capital punishment, but those convicted were often subsequently pardoned.

75. NAS JC13/82/80. 
76. Boyle (2011, pp.44-a45).

77. Poole (2008, p.172).

78. Fife Herald, Thursday 20 May 1841, p.4.

79. John O'Groat Journal, Friday 21 May 1841, p.2.

80. Fife Herald, Thursday 20 May 1841, p.4.

81. John O'Groat Journal, Friday 21 May 1841, p.2.

82. National Library of Scotland, Broadside entitled Execution shelf mark L.C.Fol. 74 (359a).

83. Emsley (2013, pp.265-267).

84. Gatrell (1994, p.544).

85. Ibid., p.103.

86. Note that the figure for the 1820 s was 52 percent.

87. Riggs (2012).

88. Cockburn (1889, p.92).

89. Pratt (2002, p.19).

90. Poole (2015, p.98).

91. McGowen (1994, p.259); Bennett (2016, Ch.3).

92. Devereaux (2009, pp.145 \&152).

93. Gatrell (1994, pp.589-591).

94. Poole (2015, p.76).

95. Emsley (2013, pp.265-267); Gatrell (1994, p.544); Bennett (2016, p.64).

\section{ABSTRACTS}

Early nineteenth-century Britain witnessed rising numbers of offenders facing capital punishment and a plethora of legal and public discourse debating the criminal justice system. This article will examine a distinct Scottish response to the problem in the form of crime scene executions. By the turn of the nineteenth century, it had long been the established practice of the Scottish courts to order that capitally convicted offenders would be executed at an established "common place". However, between 1801 and 1841, the decision was taken to execute thirty-seven offenders at the scene of their crimes. This article argues that, in the face of an unprecedented number of offenders facing the hangman's noose, the Scottish judges chose to exercise this penal option which had not been used to a similar extent since the mid-eighteenth century. In turn these events had a multiplicity of impact and provoked responses ranging from a morbid curiosity to witness the spectacle to anxiety and outright disdain at its intrusion into areas previously unsullied by the last punishment of the law.

La Grande-Bretagne du début du 19e siècle connut un nombre croissant de condamnés à mort et un débat public et juridique massif concernant le système pénal. Le présent article examine une réaction à cette question spécifique à l'Écosse, sous la forme de l'exécution sur les lieux du crime. $\mathrm{Au}$ tournant $\mathrm{du} 19^{\mathrm{e}}$ siècle, les tribunaux écossais avait établi de longue date la pratique selon laquelle les condamnés capitaux seraient exécutés dans un «lieu public » désigné. Cependant , entre 1801 et 1841, il fut décidé d'exécuter 37 condamnés sur les lieux de leurs crimes. Le présent article argue que, face à ce nombre sans précédent de criminels promis au gibet, les juges écossais décidèrent d'utiliser ce moyen, qui n'avait plus été employé à cette échelle depuis le milieu du $18^{\mathrm{e}}$ siècle. En retour, ces évènements eurent de multiples effets et provoquèrent des 
réactions allant de la curiosité morbide à l'observation de ce spectacle jusqu'à l'anxiété et le mépris affiché vis-à-vis de cette intrusion dans des lieux qui, jusqu'alors, avaient échappé à la souillure de l'ultime peine légale.

\section{AUTHOR}

\section{RACHEL BENNETT}

Rachel Bennett earned her PhD from The University of Leicester in 2016 with a thesis entitled "Capital Punishment and the Criminal Corpse in Scotland 1740 to 1834". It was part of a major research initiative funded by the Wellcome Trust entitled, Harnessing the Power of the Criminal Corpse. She is the author of the book chapter: "A Candidate for Immortality: Martyrdom, Memory and the Marquis of Montrose" in Shane McCorristine (ed), Interdisciplinary Perspectives on Mortality and its Timings: When is Death? Basingstoke, Palgrave Macmillan, 2017, Department of History, University of Warwick, Coventry, CV4 7AL - rachelelizabethbennett@gmail.com 